\title{
INTER-COMMUNAL COOPERATION AND REGIONAL DEVELOPMENT: THE CASE OF ROMANIA
}

\author{
RADU SăGEATĂ \\ Institute of Geography, Romanian Academy, Bucharest, Romania \\ Manuscript received: June 5, 2011 \\ Revised version: May 23, 2012
}

\begin{abstract}
SĂGEATĂ R., Inter-communal cooperation and regional development: The case of Romania. Quaestiones Geographicae 31(2), Bogucki Wydawnictwo Naukowe, Poznań 2012, pp. 95-106. 2 tables, 3 figs. DOI 10.2478/v10117-0120022-8, ISSN 0137-477X.

AвSTRACT. Romania's local administrative-territorial organisation shows a high degree of fragmentation. The situation tends to worsen as some villages break away from the parent communes and form new administrative-territorial structures. Since their area is fairly small and adequate financial resources to sustain some coherent, long-term development programmes are missing, a solution would be for them to associate freely into inter-communal cooperation structures, which is a basic prerequisite for attracting European structural funds. Such a type of cooperation practice was experienced in this country at the beginning of the 20th century. Today, inter-communal cooperation could be achieved in two ways: by an association of local communities patterned on historical 'lands' (after the French model) and by the establishment of a town, of the metropolitan type, to polarise cooperation structures.
\end{abstract}

KEY WORDS: administrative fragmentation, inter-communal cooperation, regional development, Romania

Radu Săgeată, Institute of Geography, Romanian Academy, 12 Dimitrie Racoviță, 023993, Bucharest, Romania; e-mail: radusageata@yahoo.com

\section{Introduction}

With the numerical increase in communes, a local tendency to fragmentation has become obvious, especially after $2000^{1}$. This situation calls for a new territorial planning strategy, either by creating an under-departmental type of administration resembling the French arrondissement (or a small rural district - the plasă of inter-war

Out of the 238 new communes formed between 1990 and 2011, only 5 held this rank before 2000. This evolution is the result of the local communes' desire for self-administration, also encouraged by the governments that came to power after the elections of 2000. Some rural communities situated at the periphery of the existing communes perceived themselves marginalised and decided to separate and form new communal centres. As a matter of fact, many of them had commune-seat status before 1950 .
Romania), or by having new, flexible structures of inter-communal association based on common interests and established by people's free accord. In the first case, the political-administrative decision rests with the centre and is sanctioned in a referendum; in the second case, the initiative belongs exclusively to the local communities. From this viewpoint, we consider that extrapolating the French pays model to Romania would be a useful and beneficial experiment with a positive impact on the evolution of the Romanian village. We use the term 'village' because, with a few exceptions, the new urban nuclei created after 1945 have not become real polarisation cores with urban functions. In most cases, whether they enjoy urban status or remain rural settlements lately benefiting from European rural development 
programmes, their evolution has been very much the same.

The administrative-territorial map of Romania, both in the present variant and in the one proposed as an optimisation model, shows great fragmentation at the local level: 2,926 communes and 320 towns, of which 103 are municipia ${ }^{2}$ (January 1,2011$)$. The fragmentation is expected to continue as some villages tend to break away from the existing communes and develop into new administrative structures.

This process can be considered beneficial, falling in line with the action of assigning some villages communal status which they held before 1968. Re-establishing all the 1,551 communes dismantled in 1968 would reduce the average size of local administrative structures (currently $80.27 \mathrm{~km}^{2}$ ) to $53.64 \mathrm{~km}^{2}$; a comeback to the 1925 situation would mean an area of only $33.6 \mathrm{~km}^{2}$. Since local structures have the characteristics required by identity spaces, delimiting them needs the agreement of the respective local communities and not the establishment of demographic or financial thresholds, and even less of administrative boundaries imposed from outside.

A small area and the absence of adequate financial resources to sustain some coherent longterm development programmes would suggest that the free association within inter-communal cooperation structures could be a solution to obtain the European structural funds over the 2007-2013 period. Inter-communal cooperation structures represent associative structures of cooperation among territorial communities at the commune level, a type of cooperation already

Table 1. Change in the number of Romanian administrative-territorial units (1990-2010).

\begin{tabular}{|c|c|c|c|}
\hline Year & Towns & $\begin{array}{c}\text { of which } \\
\text { municipia }\end{array}$ & Communes \\
\hline 1990 & 260 & 56 & 2,688 \\
\hline 2010 & 320 & 103 & 2,926 \\
\hline
\end{tabular}

2 In Romania's legislation, the municipium (pl. municip$i a)$ is defined as a city with a large number of inhabitants that has a special economic, socio-political and cultural-scientific importance in the country's life. Another normative act later has established precisely and clearly the demographic indicators, location advantages, and economic and physical-infrastructure facilities for a city to be declared a municipium. experimented with by Romanian administrative practice at the beginning of the 20th century.

\section{Evolution of inter-communal cooperation in Romania}

The very definition of the commune shows it to be an associative structure: an administrativeterritorial unit which comprises the rural population united by common interests and traditions, and includes one or several villages in terms of economic, socio-cultural and geo-demographic conditions (Erdeli et al. 1999: 83).

The commune, institutionalised after the unification of principalities by the Communal Act of April 1, 1864, was to have 100 families or 500 inhabitants. In this way, 2,905 communes came into being in the two principalities of Wallachia and Moldavia. The average area of a commune was $47.5 \mathrm{~km}^{2}$. Because of high local fragmentation and because communal administrative structures had a small area and population, the formation of sufficiently large budgets to achieve real financial autonomy was rare. Therefore, the Act of May 1, 1904 stipulated that a commune must have 800 inhabitants and a minimum income of 8,000 lei (Nistor 2000). Out of the 2,905 communes, only 299 met this criterion, the others would associate and form 962 communal rings, each having to finance a minimum of health and public order services.

The communal rings functioned only four years, being dissolved by the Act of April 29, 1908, which laid down a basis for a lucrative system of associations of local territorial communities to perform or keep up some public works of local economic, cultural or technical-urban utility.

The main legal provision regulating the local communities' associative system at the commune level was the Administrative Unification Act (June 14, 1925), which promoted excessive centralism materialised in small administrative

\footnotetext{
Under this law, the communes, defined as administrative-territorial units with juristic-person status, included "all villages, towns and small towns (boroughs)". It was only after 30 years that a distinction would be made between the rural and the urban commune (Act of July 31, 1894) as the technological progress of society had widened the gap between urban and rural environments.
} 
units: whenever possible, each village was to be turned into a commune. However, this was not feasible in practice because Wallachian, Moldavian and some Bessarabian communes had very low incomes. What emerged were 8,751 communes (the largest number of local administrative-territorial units ever recorded in Romania) comprising 15,267 villages. And again, the large number and extremely low financial power made local autonomy simply a desideratum, a mere formality. Therefore, this law maintained the system of lucrative associations initiated in 1908 (but dissolved in 1959) when the Peasant Party, then in government, with Juliu Maniu as Prime Minister, opted for the establishment of large administrative units capable of having true local autonomy. In this way, the number of communes dropped drastically from 8,751 to 1,500 , but that of villages remained unchanged. In order to establish a commune, it was necessary to have over 10,000 inhabitants and a local income higher than 500,000 lei. The opposition, especially the National Liberal Party, voiced its discontent and, when it came to power, resumed the 1925 principles of extreme centralisation (the Administrative Act of 1936).

After 1950, the communist rule reduced local initiatives simply to acts of acquiescence in party and state decisions, local autonomy became formal, and the institutional framework of inter-communal association was eliminated. The number of communes was steadily being reduced: 8,751 in $1936 ; 4,313$ in $1956^{4} ; 4,259$ in 1960; 2,706 in $1968 ; 2,326$ in 1989 ; but was up to 2,869 on July 1, 2005.

The Romanian legislation provides only for contract-based cooperation between local territorial communes through the agency of local councils. Their task is to undertake works and services of public interest and collaborate with economic agents on the basis of agreements for works of common interest. The normative acts stipulating the above include the Local Public Administration Act, the Public Finance Act, and the Local Public Finance Act (Popescu 1999).

4 However, they increased to the 1956 figure of 4,313 from 4,052 in 1950.

\section{Inter-communal cooperation in post- communist Romania. Premises and evolution}

The steep economic decline of the 1990s was amply reflected also by political-administrative decisions, which shifted from the ideological to a predominantly economic perspective. A first step in this direction had in view the principle of restitutio in integrum, which characterised most political decisions in matters of legislation up to the mid-1990s, when a number of laws were passed regulating the situation of nationalised houses, rehabilitating some political personalities active mainly in the inter-war period, and stipulating an objective presentation of Romania's contemporary history and the communist system, in an attempt to correct the arbitrary decisions made by the regime abolished in 1989. In line with this rehabilitation policy, it was decided that the administrative-territorial structures dismantled in 1950 should be re-established.

Romania's official request for EU membership lodged on June 22, 1995 opened up the road to negotiations for adopting the European Community acquis. As regards the administrative-territorial structures, that moment marked the development of initiatives to set up territorial units comparable in area and demographic size to regions in Europe. The idea of integrating former administrative structures gained ground against proposals of fragmentation based on the reconstruction on the former county pattern. As a result, the eight development regions established in $1997^{5}$ constituted the territorial framework for the implementation of regional development policies ${ }^{6}$.

While at the macro-territorial level there is a tendency to create administrative structures patterned on the European region type, at the micro-territorial level tendencies are just the opposite, basically towards fragmentation, as new local administrative structures are expected to emerge by spinning off from the existing ones.

\footnotetext{
They were mentioned in the Green Paper. Regional Development Policy in Romania worked out by the Government and the European Commission under the PHARE Programme.

6 These were legislated in July 1998 (see Regional Development Act No. 151, art. 5 and 6).
} 
Generally, history and local patriotism (re-establishing the communes abusively dismantled in 1950 and 1968$)^{7}$ are the motives put forward, but the true reasons behind the decisions to set up new communes are rather of an economic and political nature.

The overall economic decline in the post-1989 period, shown in the severe degradation of the means of production and fixed assets which had belonged to former collective farms (buildings, warehouses, animal sheds, irrigation systems, plant nurseries, solariums, etc.), contributed to the worsening of the situation of the aged and feminised rural population inherited from the communist regime and its forcible industrialisation policy. In these conditions, convincing people who had lost their jobs in the process of urban industrial restructuring to go to the countryside was a pretty difficult task, even though the land law provided for the restitution of property and the government offered financial assistance. In addition, the general money shortage led to a steady degradation of technical-construction infrastructure, also enhancing the consequences of some extreme climatic and geomorphological phenomena (floods, droughts, landslides) that affected very many rural communities, increasing endemic poverty and the feeling of dependence on local administration, which appeared to be indifferent to villagers' problems.

Location is also very important. There are many isolated villages or communes undergoing depopulation, and so people there tend to set up their own administrative structures and spare the long and costly journey (of tens of kilometres sometimes) to the communal seats.

In this way, the separation of some villages and the formation of new communes with fewer inhabitants is an attempt to solve the economic and social situation of some local communities in the hope that self-administration is more efficient, efficiency being a major prerequisite in the allocation of extra-budgetary funds. In many cases, however, these initiatives hide local interests in the guise of mayors' strong attachment to their electorate. In reality, this scheme results in an overexpanded bureaucratic apparatus and

The 8,751 communes in place under the 1925 administrative-territorial organisation were reduced to 4,052 in 1950, 2,706 in 1968 and 2,326 in 1989. corruption, thus discouraging entrepreneurial initiatives.

And so, between January 1, 1990 and January 1, 2011, 238 new communes came into being (Fig. 1 ). The peak moment of that action was 20022004, after the Management of the National Territory Plan - Section IV: The Settlements Network was adopted in July $2001^{8}$. This normative act established the legal framework stipulating the minimum and maximum criteria for changing the status of communes to towns and of towns to municipia. But in many cases villages proposed as county-seats ignored the conditions imposed by the law; moreover, political decisions made under the pressure put by the local authorities to set up new communes and bring in entrepreneurial activities were often subjective, because those communes had not the economic potential which would have entitled them to those promotions.

Since administrative fragmentation at the communal level keeps progressing, contract-based cooperation among local territorial communities is not only a functional modality, but also a very useful one. This would help attaining some objectives of public interest (infrastructure, services) and facilitate collaboration with economic agents for works of common interest on the basis of public-private partnership agreements. A good example in this respect is the French pays (Săgeată 2004a, b, 2005, 2006).

In France, inter-communal cooperation has got a long tradition, given that extended administrative fragmentation has been a landmark there. With its 36,700 communes, France has the most fragmented local administration throughout the European Community, ranking far behind any other of its member states. In Germany, for example, the merging of communes in the 1970s left only 8,500 units from the former total of 24,000; in France the process took on a reverse course, similar to that foreseeable for Romania. Also the causes underlying those changes are similar, in principle people's profound attachment to their

\footnotetext{
8 Act 351/July 6, 2001, published in the Official Bulletin of Romania, XIII, 408 of July 13, 2001.
} 


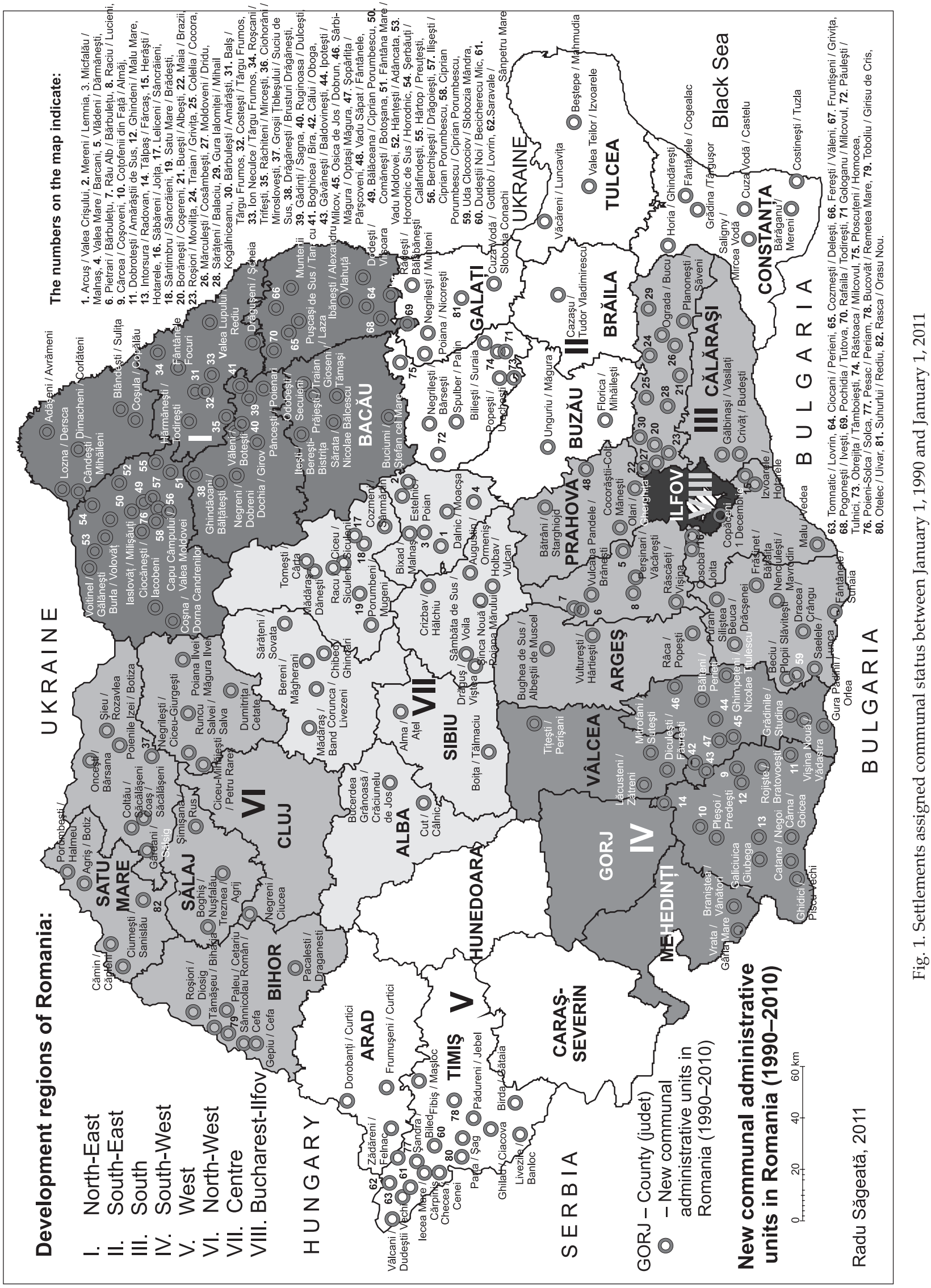


locality ${ }^{9}$, which is strongly identified mentally with local autonomy, local specificity against a centralised administrative system. The mayors, who were the first to be requested to state their opinion on the numerical reduction of communes, were keen to oppose the merger, usually invoking their obligation to the electorate. So, nearly $80 \%(28,600)$ of the overall number of communes have under 1,000 inhabitants and $61 \%$ even fewer than 500; in this way, the necessary services for actually discharging the attributes of local power are missing. Besides, the average area of a French commune is very small, no more than $15.1 \mathrm{~km} 2$, many having even under $10 \mathrm{~km}^{2}$. This situation prompted two territorial polarisation acts (in 1995 and 1999) institutionalising inter-communal cooperation by way of setting up communities of communes and pays.

While the French pays have emerged relatively recently, the Romanian geographical space has recorded them since as far back as the early Middle Ages (1200-1300). With time, "lands" (pays) have acquired some features which define them as specific geographical regions of Romania (Ilieş 1999). By the level of importance, "lands" hold a lower rank than the historical provinces, but higher than the commune-type local communities. "Lands" stand out as the most characteristic mid-level functional territorial structures in Romania. That they are viable structures has been proved by their great temporal stability, having become actual landmarks of the local people's identity, of their mental, ethnographic and life experience (l'espace vécu) (Cocean 2002). This function is augmented by local polarisation cores, which have registered a remarkable development through investments in rural tourism and agro-tourism.

Like the French pays, the Romanian "lands" do not cover the whole national territory, but only old pockets of settlement, corresponding as a rule to depression areas used as shelter-places (Table 2).

But for all their political and political-administrative functions discharged throughout history to the present day, and despite represent-

\footnotetext{
In France the commune is identified with the administrative territory of the human settlement (rural or urban), and no other units (of the village-type as in Romania) enter its fabric.
}

ing well-individualised regional spaces, "lands" in Romania, unlike their counterparts in France, have never enjoyed a legally institutionalised status. We consider that a normative act setting things right would be highly beneficial. Such an act should provide for their institutionalisation, and for the establishment of some inter-communal cooperation structures scheduled to overlap the historical "lands".

The presence of some strong urban nuclei capable of effectively polarising local settlement systems might help some of those "lands" (Maramureş Land, Dorna Land, Bârsa Land, Făgăraş Land, and Amlaş Land) develop into under-departmental type administrative structures, an aspect taken into account when working out the administrative framework proposed as an optimisation model (Săgeată 2004a, b, 2006). Their functional capacity is reflected in people's psychology, the region becoming a mental space and an ethnographic space, a space with which inhabitants identity themselves, expressing the communion between man and his environment, a reality fundamental to sustaining any territorial organisational structure. Mental spaces are at the same time functional spaces, as well as spaces of cultural homogeneity, structured from bottom to top on the basis of relationships among the local communities. Most European regions are in effect mental spaces shaped in the course of a long historical process. There are cases when people's regional identity is stronger than their national one (e.g. Flanders and Wallonia in Belgium, the German and Austrian lands, the Swiss cantons, or some of the Spanish autonomous communities). Therefore, we consider that the regions which, through inter-communal cooperation have in time become mental spaces are the most viable ones and, irrespective of size, deserve being vested with administrative status.

However, in our opinion, the first and most important obstacle to forming inter-communal cooperation structures in Romania's rural areas (Fig. 2) is the local psyche. Unlike the French, who have a positive perception of participatory practices, of partnership among local communities, or between various institutions and the local actors, liable to produce mutual benefits, the Romanian peasant has experienced decades of forcible collectivisation. Therefore, he is extremely 
reluctant to take such a move, because the idea of an inter-communal system, of collective participation, is perceived as a comeback to the communist principles. A good illustration of the above is the fundamentally different acceptance given by the French and the Romanians to the term 'agricultural production cooperative'.

Consequently, in order to make people realise that things have indeed changed, and that the new forms of association have nothing in common with the past situations, local communities have to be well informed. Otherwise, any local initiative tends to be blocked from the very outset by prejudice accumulated over decades of collectivisation.

Establishing inter-communal cooperation structures patterned on 'disadvantaged (less-favoured) zones', usually with only one industrial enterprise on their territory, and this one in the process of restructuring, as well as a very weak potential for occupational diversification, appears to be a failed experiment in stimulating regional development. In many situations, in the absence of precise legal regulations, this type of zone has favoured tax evasion, because instead of creating jobs for the locals by processing existing raw materials and benefit from fiscal assistance,

Table 2. Main ethnographic mental spaces in Romania by spatial level.

\begin{tabular}{|c|c|c|}
\hline Macro-space & Middle space & Micro-space \\
\hline Historical provinces & PAYS ("LANDS") & Communes \\
\hline \multirow[b]{2}{*}{ BANAT } & $\begin{array}{c}\text { ALMĂJULUI } \\
\text { (Tinutul } \sim) \\
\text { (Caraş Severin County) }\end{array}$ & $\begin{array}{c}\text { Bozovici*, Lăpuşnicu Mare, Dalboşeț, Bănia, Şopotu Nou, Prigor } \\
\text { and Eftimie Murgu }\end{array}$ \\
\hline & $\begin{array}{l}\text { PADURENILOR (Tinutul } \\
\sim \text { ) } \\
\text { (Hunedoara County) }\end{array}$ & $\begin{array}{c}\text { Hunedoara*, Bătrâna, Bunila, Cerbăl, Dobra, Ghelari, Lelese, } \\
\text { Pestişu Mic, Toplița and Vețel }\end{array}$ \\
\hline \multirow{2}{*}{ BUCOVINA } & $\begin{array}{l}\text { CÂMPULUNGULUI } \\
(\text { Ocolul } \sim) \\
\text { (Suceava County) }\end{array}$ & $\begin{array}{c}\text { Câmpulung Moldovenesc*, Vama, Pojorâta, Sadova, Fundu } \\
\text { Moldovei, Frumosu and Frasin }\end{array}$ \\
\hline & $\begin{array}{l}\text { DORNEI (Tara }) \\
\text { (Suceava County) }\end{array}$ & $\begin{array}{c}\text { Vatra Dornei*, Dorna Candrenilor, Dorna Arini, Iacobeni, Panaci, } \\
\text { Şaru Dornei and Poiana Stampei }\end{array}$ \\
\hline \multirow{3}{*}{ CRIŞANA } & $\begin{array}{l}\text { BEIUŞULUI (T,Tara ) } \\
\quad \text { (Bihor County) }\end{array}$ & $\begin{array}{c}\text { Beiuş*, Pocola, Remetea, Căbeşti, Curățele, Budureasa, Tărcaia, } \\
\text { Finiş, Şoimi, Uileacu de Beiuş, Drăgăneşti, Lazuri de Beiuş, } \\
\text { Bunțeşti, Rieni, Pietroasa, Ştei, Lunca, Câmpani, Vaşcău, Nucet, } \\
\text { Cărpinet and Criştioru de Jos }\end{array}$ \\
\hline & $\begin{array}{l}\text { SILVANIEI (T, Tara ) } \\
\text { (Sălaj County) }\end{array}$ & $\begin{array}{c}\text { Şimleu Silvaniei*, Pericei, Vârşolț, Crasna, Horoatu Crasnei, } \\
\text { Cizer, Bănişor, Sâg, Vălcău de Jos, Nuşfalău and Ip }\end{array}$ \\
\hline & $\begin{array}{l}\text { ZARANDULUI (Tara ) } \\
\quad(\text { Arad County) }\end{array}$ & $\begin{array}{l}\text { Sebiş*, Vârfurile, Pleşcuța, Gurahonț, Brazii, Dieci, Almaş, } \\
\text { Chisindia, Dezna, Igneşti, Moneasa, Buteni, Bârsa, Bocsig, } \\
\text { Şilindia, Tăuț and Cărand }\end{array}$ \\
\hline DOBROGEA & - & 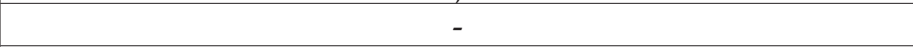 \\
\hline \multirow[t]{2}{*}{ MARAMUREŞ-OAŞ } & $\begin{array}{l}\text { MARAMUREŞULUI } \\
\quad(\text { Tara } \sim) \\
\text { (Maramureş County) }\end{array}$ & $\begin{array}{c}\text { Sighetu Marmației*, Sarasău, Câmpulung la Tisa, Săpânța, } \\
\text { Remeți, Giuleşti, Vadu Izei, Călineşti, Deseşti, Ocna Şugatag, } \\
\text { Bârsana, Rona de Jos, Rona de Sus, Bocicoiu Mare, Budeşti, } \\
\text { Botiza, Strâmtura, Ieud, Dragomireşti, Rozavlea, Leordina, } \\
\text { Ruscova, Repedea, Bistra, Vişeu de Sus, Vişeu de Jos, Poienile de } \\
\text { sub Munte, Poienile Izei, Bogdan Vodă, Moisei, Borşa, Săcel and } \\
\text { Siliştea de Sus }\end{array}$ \\
\hline & $\begin{array}{l}\text { OAŞULUI (T,ara ) } \\
\text { (Satu Mare County) }\end{array}$ & $\begin{array}{c}\text { Negreşti-Oaş*, Vama, Certeze, Bixad, Călineşti-Oaş, Oraşu Nou, } \\
\text { Târşolț, Cămârzana and Gherța Mică }\end{array}$ \\
\hline MOLDAVIA & $\begin{array}{l}\text { VRANCEI (T,Tara } \sim) \\
\text { (Vrancea County) }\end{array}$ & $\begin{array}{c}\text { Năruja*, Vrâncioaia, Nistoreşti, Bârsăneşti, Valea Sării, Paltin, } \\
\text { Vidra, Reghiu, Andreiaşu de Jos, Nereju and Tulnici }\end{array}$ \\
\hline $\begin{array}{l}\text { WALLACHIA } \\
\text { (MUNTENIA) }\end{array}$ & - & - \\
\hline \multirow[b]{2}{*}{ OLTENIA } & $\begin{array}{l}\text { LOVIŞTEI (T,ara ) } \\
\text { (Vâlcea County) }\end{array}$ & $\begin{array}{c}\text { Brezoi*, Mălaia, Voineasa, Racovița, Câineni, Boişoara and } \\
\text { Perişani }\end{array}$ \\
\hline & $\begin{array}{l}\text { SEVERINULUI (Tara ) } \\
\text { (Mehedinți County) }\end{array}$ & $\begin{array}{l}\text { Drobeta-Turnu Severin*, Breznița-Ocol, Izvoru Bârzii, Malovăț, } \\
\text { Şimian and Husnicioara, Căzăneşti, Şişeşti }\end{array}$ \\
\hline
\end{tabular}


Table 2. cont.

\begin{tabular}{|c|c|c|}
\hline Macro-space & Middle space & Micro-space \\
\hline Historical provinces & PAYS (“LANDS”) & Communes \\
\hline \multirow{14}{*}{ TRANSYLVANIA } & $\begin{array}{l}\text { AMLAŞULUI (T,ara ) } \\
\quad(\text { Sibiu County) }\end{array}$ & $\begin{array}{l}\text { Sibiu*, Cisnădie, Sadu, Tălmaciu, Râu Sadului, Răşinari, Poplaca, } \\
\text { Orlat, Gura Râului, Sălişte, Cristian, Tilişca, Şelimbăr, Ocna } \\
\text { Sibiului, Şura Mică, Şura Mare, Roşia, Vurpăr, Slimnic and } \\
\text { Loamneş. }\end{array}$ \\
\hline & $\begin{array}{l}\text { BÂRSEI (T⿱⺌兀ara } \sim) \\
\text { (Braşov and Covasna } \\
\text { counties) }\end{array}$ & $\begin{array}{l}\text { Braşov*, Săcele, Codlea, Ghimbav, Râşnov, Cristian, Vulcan, } \\
\text { Brad, Moieciu, Zărneşti, Poiana Mărului, Şinca Nouă, Târ- } \\
\text { lungeni, Budila, Teliu, Dobârlău, Hărman, Prejmer, Sânpetru, } \\
\text { Hălchiu, Bod, Dumbrăvița, Feldioara, Hăghig, Măieruș, Apața, } \\
\text { Belin, Vâlcele, Ilieni, Chinchiş, Dobârlău, Ozun, Sfântu Gheo- } \\
\text { rghe, Valea Crişului, Bodoc, Ghidfalău, Reci, Moacşa, Boroşneu } \\
\text { Mare, Brateş, Covasna, Zăbala, Ghelința, Cătălina, Cernat, Târgu } \\
\text { Secuiesc, Turia, Sânzieni, Poian, Ojdula, Brețcu and Lemnia }\end{array}$ \\
\hline & $\begin{array}{c}\text { BISTRIȚEI (T, Tara ) } \\
\text { (Bistrița-Năsăud County) }\end{array}$ & $\begin{array}{c}\text { Bistritta*, Sieu-Măgheruş, Budacu de Jos, Cetate, Livezile, Josenii } \\
\text { Bârgăului, Prundu Bârgăului, Tiha Bârgăului, Mărişelu, Şieu, } \\
\text { Şieuț and Monor }\end{array}$ \\
\hline & $\begin{array}{l}\text { CHIOARULUI (Țara } \sim \text { ) } \\
\text { (Maramureş County) }\end{array}$ & $\begin{array}{l}\text { Şomcuta Mare*, Remetea Chioarului, Copalnic Mănăştur, Satu } \\
\text { Lung, Săcălăşseni, Mireşu Mare and Valea Chioarului. }\end{array}$ \\
\hline & $\begin{array}{l}\text { CIUCURILOR (Tara ) } \\
\text { (Harghita County) }\end{array}$ & $\begin{array}{l}\text { Miercurea Ciuc*, Păuleni-Ciuc, Siculeni, Frumoasa, Mihăileni, } \\
\text { Dăneşti, Cârța, Sândominic, Sâncrăieni, Sânsimion, Sânmartin, } \\
\text { Ciucsângeorgiu, Bălan, Tuşnad and Băile Tuşnad }\end{array}$ \\
\hline & $\begin{array}{l}\text { FĂGĂRAŞULUI } \\
\text { (Țara ) } \\
\text { (Braşov County) }\end{array}$ & $\begin{array}{l}\text { Făgăraş*, Mândra, Şercaia, Şinca, Hârseni, Recea, Voila, Beclean, } \\
\text { Lisa, Victoria, Viştea, Ucea, Şoars, Cincu, Bruiu, Chirpăr, Arpaşu } \\
\text { de Jos, Cârța, Porumbacu de Jos, Avrig and Racovița }\end{array}$ \\
\hline & $\begin{array}{l}\text { GIURGEULUI (Țara ) } \\
\text { (Braşov County) }\end{array}$ & $\begin{array}{l}\text { Gheorgheni*, Lăzarea, Ditrău, Remetea, Subcetate, Sărmaş, } \\
\text { Gălăuțaş, Toplița, Joseni, Ciumani, Suseni and Voşlăbeni }\end{array}$ \\
\hline & $\begin{array}{l}\text { HAȚEGULUI (Țara } \sim \text { ) } \\
\text { (Hunedoara County) }\end{array}$ & $\begin{array}{l}\text { Deva*, Hunedoara, Călan, Simeria, Turdaş, Băcia, Mărtineşti, } \\
\text { Boşorod, Bretea Română, Hațeg, Sântămăria-Orlea, Toteşti, Gen- } \\
\text { eral Berthelot, Cârjiți, Peştişu Mic }\end{array}$ \\
\hline & $\begin{array}{c}\text { HOMOROADELOR (Țara } \\
\sim \text { ) } \\
\text { (Braşov and Harghita } \\
\text { counties) }\end{array}$ & $\begin{array}{c}\text { Rupea*, Cața, Homorod, Ocland, Mereşti, Lueta, Mărtiniş, } \\
\text { Vlăhița and Copâlnița }\end{array}$ \\
\hline & $\begin{array}{l}\text { LĂPUŞULUI (T,ara ) } \\
\text { (Maramureş County) }\end{array}$ & $\begin{array}{c}\text { Târgu Lăpuş*, Lăpuş, Cupşeni, Suciu de Sus, Vima Mică, Cerneşti } \\
\text { and Coroieni }\end{array}$ \\
\hline & $\begin{array}{l}\text { MOMÂRLANILOR } \\
\text { (Tinutul }) \\
\text { (Hunedoara County) }\end{array}$ & Petroşani*, Petrila, Aninoasa, Vulcan, Lupeni and Uricani \\
\hline & $\begin{array}{l}\text { MOȚILOR (T, Tara } \sim \text { ) } \\
\text { (Alba and Hunedoara } \\
\text { counties) }\end{array}$ & $\begin{array}{l}\text { Câmpeni*, Abrud, Roșia Montană, Bucium, Bistra, Almaşu Mare, } \\
\text { Lupşa, Buceş, Vidra, Sohodol, Poiana Vadului, Scărişoara, } \\
\text { Horea, Albac, Mogoş, Vadu Moților, Întregalde, Ciuruleasa, } \\
\text { Bulzeştii de Sus, Blăjeni, Buceş, Bucuresci and Crişcior }\end{array}$ \\
\hline & $\begin{array}{l}\text { NĂSĂUDULUI (Țara ) } \\
\text { (Bistrița-Năsăud County) }\end{array}$ & $\begin{array}{c}\text { Năsăud*, Rebrişoara, Rebra, Feldru, Ilva Mică, Coşbuc, Salva, } \\
\text { Zagra, Nimigea, Chiuza, Şintereag, Dumitra, Telciu, Şintereag, } \\
\text { Dumitra, Telciu, Şieu-Odorhei }\end{array}$ \\
\hline & $\begin{array}{c}\text { PRAIDULUI (Tara } \sim \text { ) } \\
\text { (Harghita and Mureş coun- } \\
\text { ties) }\end{array}$ & Sovata*, Praid and Corund \\
\hline
\end{tabular}

*In italics: settlements acting as polarising centres (central places).

many entrepreneurs use the 'disadvantaged zone' regime to eschew taxation while running their companies elsewhere. In this way, the impact of this venture on the local communities of disadvantaged zones themselves is anything but positive. On the other hand, the selection of local communities to be listed as disadvantaged is rather arbitrary, given that vast areas from Moldavia and the Bărăgan Plain, plagued by endemic poverty, profiled on one industrial unit alone and 


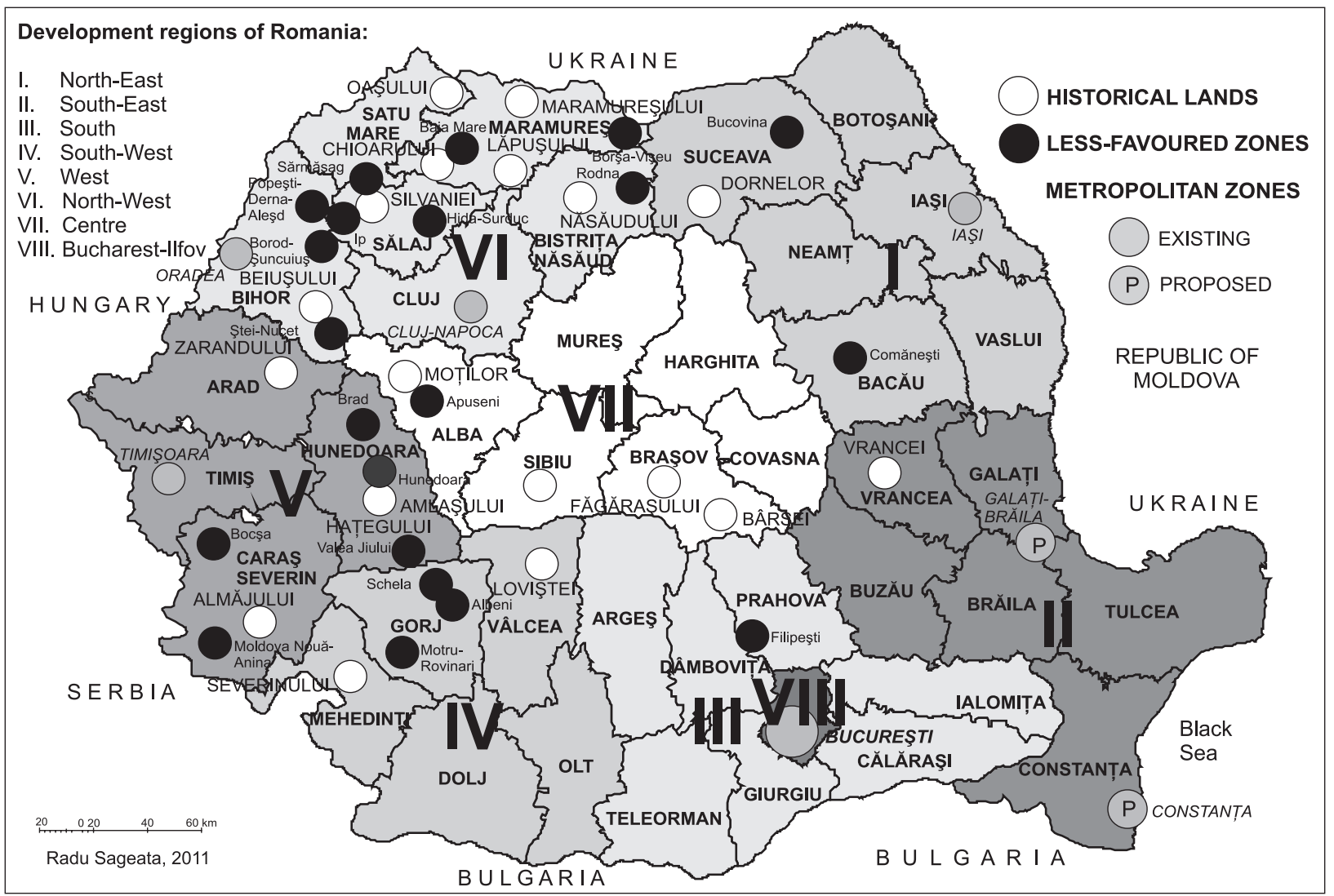

Fig. 2. Inter-communal cooperation structures.

largely dependent on the climate, have not been included in this category. The rush to have as many disadvantaged zones as possible (embracing $7 \%$ of the country's area and about $6.5 \%$ of its population) had not the expected investment effect, and since legislative measures appeared to be ineffective, the whole scheme was abandoned. This aspect is mirrored also by the pattern and duration of the 'disadvantaged area' regime. The first such areas (designated in 1998 and 1999) were formed by inter-communal cooperation and represented extensive territorial structures $(\mathrm{Bu}-$ covina, Moldova Nouă-Anina, Brad, the Apuseni Mountains, the Jiu Valley, etc.); the latest ones (established in 2000 and 2001) were limited to one administrative unit only.

On the other hand, inter-communal cooperation in the peri-urban areas within the framework of metropolitan zone associations ${ }^{10}$ is fully viable because the two types of area are perfectly complementary: the town has the biggest local budg-

10 With the exception of the country's capital, the term "metropolitan zone" is inappropriate for towns in Romania (Săgeată 2004b). et, a high population density, high land prices, and a small administrative territory; the peri-urban area has limited financial resources, but land in excess. The high land prices in town make investments migrate to the peri-urban zone, and so administrative boundaries become simply a formality, the town expanding beyond its administrative limits, and the rural zone evolving from polarised to integrated space. So, inter-communal cooperation becomes essential in stimulating entrepreneurial initiatives towards integrated regional development.

The formation of some metropolitan zones similar to the municipalities of Oradea, Timişoara, Cluj-Napoca or Iaşi and to the Bucharest Metropolitan Zone is based on this type of inter-communal cooperation. I suggest the extension of this kind of partnership also to other urban centres, such as the Galați-Brăila bipolar conurbation, or the urbanised seaside area under the influence of the Constanța municipality (Săgeată 2004a, b, 2006).

A second trend in the evolution in the ruralurban interface, manifesting itself on the vertical 
plane this time ${ }^{11}$, is the increasing transformation of communes viewed as local polarisation cores into towns (Act No. 351/2001, annex II-6.1 designated 17 zones with no town within a radius of 25-30 km which were to develop urgently into localities performing the inter-communal servicing role). In this way, the Romanian urban system was enlarged (2001-2005) with 53 of the 58 settlements raised to town status after 1989. Their demographic size, physiognomy and functional profile justify the assumption that post-communist urbanisation, just like the urbanisation pursued in the years of the centralised economy, had an extensive, quantitative character rather than the intensive, qualitative attributes capable of creating better urban comfort and functional convergence between the top and the bottom of the urban hierarchy.

Multiplying the number of towns (Fig. 3) in conditions where large areas are not, or little, polarised by an urban core, may be well-intentioned, but it tends to remain simply declarative if these towns are not capable of growing into real local polarisation nuclei and playing a coagulating role in the territory. Besides, the minimum legal criteria attached to town status are usually scarcely met, many settlements preserving strong rural traits.

In the absence of standards of quality matching the urban environment, urbanisation imposed by legislation has more often than not a negative impact on the local communities, making them lose the EU funds earmarked for rural development programmes. In our view, establishing a category of settlement intermediate between the urban and the rural, similar to the urban communes of the interwar period, would be a solution. These settlements would be similar to rural ones, but would act as nurseries for the new urban settlements, which should rise to town status only after having met the necessary legal criteria.

And last but not last, a third evolution trend which has affected the Romanian settlement sys-

11 Inter-communal associations and cooperation show on the horizontal plane, in space, by functional connections established spontaneously between local communities; on the other hand, changing some units' administrative-territorial status presupposes the involvement of external decision-making bodies, a fact that would entail modifications also at the hierarchical (vertical) level. tem after 1990, has been municipium status assigned to a great many towns. While the first years of the third millennium saw some communes raised to town status, the last decade of the 20th century, basically the first phase of the transition, witnessed some towns being declared municipia. So, all of the 47 new municipia established in the post-communist period ${ }^{12}$ received this rank over the 1993-2003 period, 37 of them before January 1,2001 . The question is, what were the criteria behind pushing small towns (with fewer than 20,000 inhabitants, e.g. Urziceni, Brad, Salonta, Toplița, Orşova, Vatra Dornei, etc.) to the top of the hierarchy, and moreover, if those legislative initiatives really boosted the socio-economic development of the local communities concerned.

Whereas most municipia boast a complex industrial profile, some are one-industry towns (Câmpia Turzii and Hunedoara), agro-industrial towns (Urziceni, Salonta, Roşiori de Vede and Caracal), towns specialised in the forestry economy (Brad) or tourism (Vatra Dornei and Mangalia). Just as in the 1965-1980 interval, the diversification index of industrial branches assumed the highest values in those municipia which had experienced soaring development in the years of the centralised economy. Hence their vulnerability, caused on the one hand by artificial production relations between industrial partners, and on the other hand, by the disparity between the town's industrial profile and the resources of the urban influence zone. As a result, inter-municipia relationships also suffered some changes.

There are cases when location was the factor that determined municipium status for some towns. Thus, in intensely rural areas with smalltown networks (e.g. in the Apuseni Mountains, in the Getic Piedmont, or in south-western Oltenia), some polarising centres should be singled out to coordinate socio-economic activities. Turning such towns into municipia (Brad, Drăgăşani, Calafat, Salonta or Toplița) might attract investment helping them to become growth poles for the respective zones.

Assigning the municipium rank to towns situated on the middle or lower rungs of the urban hierarchy has widened the existing gaps in the

12 Out of the 47 municipia in 1968, we get 56 in 1989 and 103 by January 1, 2011. 


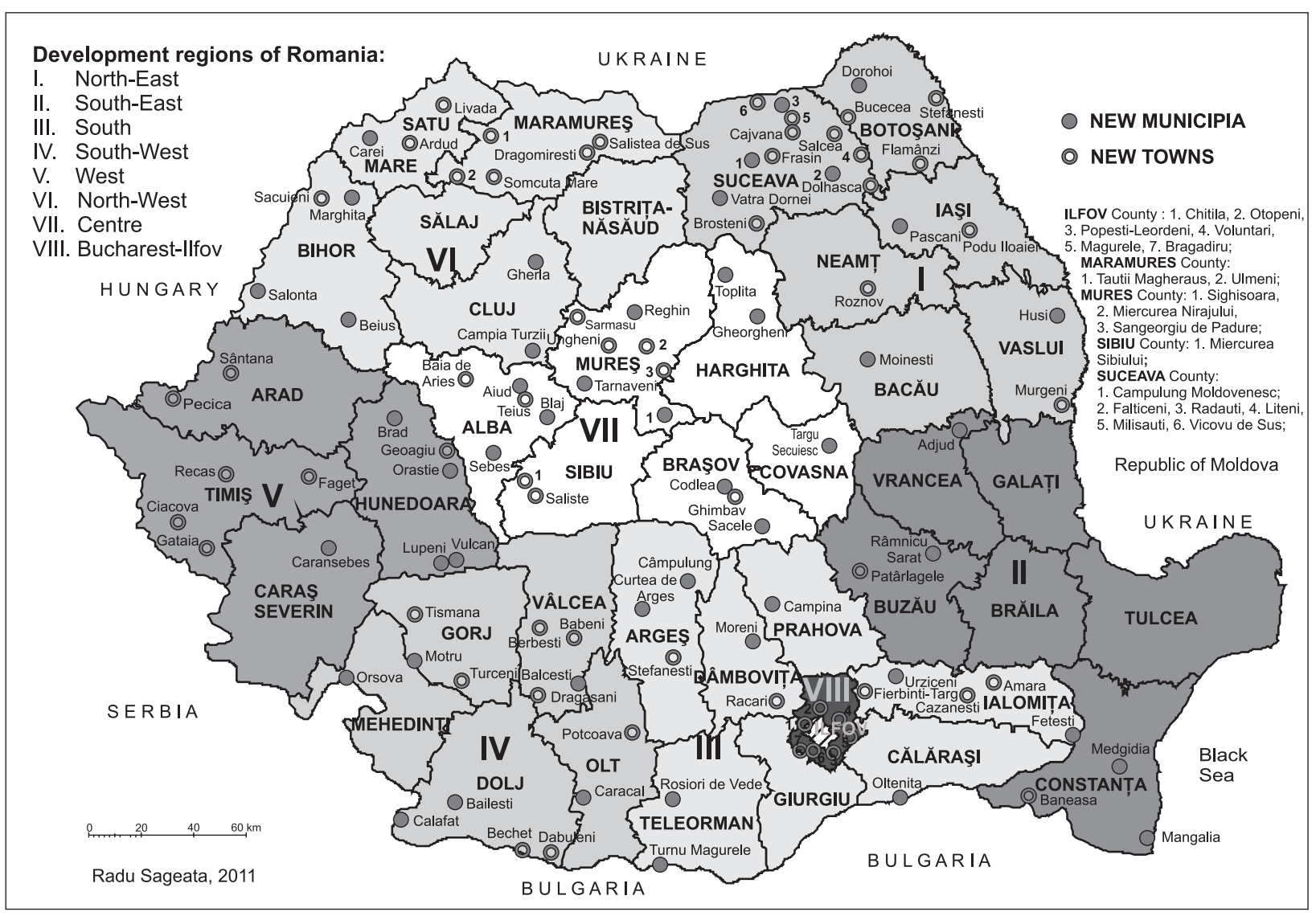

Fig. 3. Municipia and towns established between January 1, 1990 and January 1, 2011.

municipium network of Romania, so that the network shows obvious disproportions in demographic size as well as economic and location potential. The municipial population varies between 1,926,334 (Bucharest) and 10,996 (Beiuş, March 18, 2002) and if Bucharest is left out of the equation, then the ratio of extreme sizes slides from $175 / 1$ to $23 / 1$. The fact that in demographic terms the size of some municipia occupying the higher ranks of the hierarchy is bigger than of some counties (e.g. Covasna, Ilfov, sălaj, Tulcea, Giurgiu or Ialomița) calls for some deep reconsideration of their administrative pattern and the creation of districts inside their boundaries similar to those existing in Bucharest. Densities within the built-up areas of those municipia also vary widely, from over 10,000 pop. $/ \mathrm{km}^{2}$ (or even 21,855 pop. $/ \mathrm{km}^{2}$ in Oneşti to a record high 42,602 pop. $/ \mathrm{km}^{2}$ in Orăştie) to under 1,000 pop. $/ \mathrm{km}^{2}$.

In view of the above, we assume that municipium status after 1990 was often considered the optimum, even miraculous, solution for the socio-economic revival of some declining towns, and a chance to attract investment therein. In this way, a disparity appeared between their real development potential and the political-administrative decisions which tended to blur the dysfunctions produced by the excessive industrialisation drive of the old centralised economy. Soon the lack of prospects of such a development model became apparent, their socio-economic progress being little stimulated by legislative initiatives. Therefore, reshuffling the network of municipia is an imperative, affecting towns with under 50,000 inhabitants, which might be demoted from this rank.

Summing up, we would say that boosting inter-communal cooperation in Romania means creating functional structures, patterned on the historical "lands" and metropolitan zones around some viable local polarisation cores whose functional capacity has been proved in the course of time, and which have historical grounds for the creation of territorial-administrative structures in between the department and the commune, similar to the old district seats (Rom. scaun specific to the Transylvanian Saxons or Szecklers; plai, ocol, districts of the Carpathian mountain settlements; 
plasă, a small rural district; raion, the district of the 1950-1968 period). Apart from being a Soviettype administrative structures, the raions largely overlapped with some Romanian realities. Thus, some of the former district seats (the plasă or the former raion centres), especially if endowed with ethnographic or tourist functions, are potentially capable of being spatially restructured, provided someone wished to invest in their infrastructure.

\section{References}

CoCEAN P., 1997. Tara (The land) - a typical region of Romania. Revue Roumaine de Géographie, 41: 41-50.

CoCEAn P., 2002. Geografie Regională (Regional geography). Presa Universitară Clujeană, Cluj-Napoca.

ERdeli G. et al., 1999. Dicționar de geografie umană (Dictionary of human geography). Edit. Corint.

Humeau J.-B., 1992. Le regroupement intercommunal en milieu rural (Inter-communal groups in rural areas). $L^{\prime} I n-$ tercommunalité. Comité d' Expansion de Maine et Loire: $5-12$.

ILIEş M., 1999. "Țările" - regiuni geografice specifice ale României ("The lands" - specific geographical regions in Romania). Romanian Review on Political Geography, I(1): $44-49$.

Nistor I.-S., 2000. Comuna şi județul. Evoluția istorică (Commune and county. Historical evolution). Dacia, Cluj-Napoca.
Popescu C.-L., 1999. Autonomia locală şi integrarea europeană (Local autonomy and European integration). All Beck, Bucharest.

SĂGEATĂ R., 2001. "Ruralul" în mediul urban (Sings of the "rural" in the urban). Revista Geografică, VIII: 157-165.

SăgeATă R., 2004a. Dinamica zonelor de influență urbană sub presiunea functiei politico-administrative (Dynamics of urban influence zones under political-administrative pressure). Forum Geografic, III, 3: 121-126.

SĂGEATĂ R., 2004b. Zonele metropolitane în România (Metropolitan areas in Romania). Romanian Review on Political Geography, VI(1-2): 123-136.

SĂGEATĂ R., 2005. Structuri de cooperare intercomunală (Intercommunal co-operation structures). Sustainable development of rural space. Economic problems, 154-155: 30-45.

SăgeAtă R., 2006. Deciziile politico-administrative şi organizarea teritoriului. Studiu geografic cu aplicare la teritoriul României (Political-administrative decisions and organisation of the territory. Geographical study with application to Romania). Edit. Universității Naționale de Apărare „Carol I" \&, Edit. Top Form, Bucureşti.

SĂGEATĂ R., 2007. Inter-communal cooperation and territorial planning units. In: Surd V. \& Zotic V. (eds), The French experience and its applicability to Romania, rural space and local development. Presa Universitară Clujeană, Cluj-Napoca: 147-151.

SĂGEATĂ R., 2010. Regional development in Romania. Geographical studies. Edit. Universității “Lucian Blaga”, Sibiu.

Săgeată R. \& Simileanu V., 2007. Political-administrative decisions, a pressure factor for entrepreneurial initiatives. Geographica Timisensis, 16(1): 95-104. 